\title{
A Brief Economic Assessment on the Valuation of National and Natural Parks: the Case of Romania
}

\author{
Diana E. DUMITRAŞ, Felix H. ARION, Emilian MERCE \\ University of Agricultural Sciences and Veterinary Medicine, 3-5 Mănăștur, 500372, Cluj-Napoca, Romania; ddumitras@usamvcluj.ro
}

\begin{abstract}
In the last decades, an increased interest has been expressed by researchers from worldwide towards studies about economic valuation of protected areas given that environmental public goods are not always traded on a market. Economists have struggled with this subject for decades and have developed several methods to estimate the economic values of these goods, known as non-market valuation methods. This paper reviews and presents a brief analysis of the most popular techniques as applied to natural areas, which are compared after grouping the research steps in five common steps for a consistent comparative analysis. Moreover, renowned studies conducted worldwide are revealed for each of the methods. A special interest has been noticed towards the estimation of welfare measures, such as Willingness To Pay (WTP) and consumer surplus, and towards differentiating user groups, as well as introducing several factors that may influence the decision to visit the natural areas. The case of Romanian national and natural parks is discussed in detail with the purpose to emphasize the need to continue the research in the field. The unique character of each of the studied parks, marked by geographic and cultural aspects, was confirmed through statistic analyses and thus welfare measures were determined for each park separately. The performed analyses proved that the methods have applicability in Romania as well.
\end{abstract}

Keywords: non-market valuation methods, national parks, natural parks, Romania

\section{Introduction}

The management of the Romanian public land receives more and more special attention due to the recognition of the importance to protect natural areas in the benefit of current and future generations as well. In Romania, the natural areas suffered a reorganization process following the recommendation of the International Union for Conservation of Nature and Natural Resources (IUCN) to classify protected areas in six protected areas categories (IUCN, 1994). The six IUCN categories are: Strict nature reserve (Ia), Wilderness area (Ib), National park (II), Natural monument (III), Habitat/Species management area (IV), Protected landscape/seascape (V), Managed resource protected area (VI). The system was created for a better understanding of the administration of natural areas, using a common 'language' among countries, based on the primary management objective for each protected area category. The reorganization process of the natural areas was an important step towards building and maintaining a sustainable environment, integrating the principles of sustainable development in the policies and national programs and diminishing environment degradation.

The reorganization process begins starting the year of 2004, when several natural areas are designated as protected areas. The surface of protected areas has increased from $5.95 \%(1,418,340$ hectares in the year of 2000$)$ to $8.23 \%$ $(1,961,238$ hectares in the year of 2010$)$ of the total pro- tected areas surface. National (equivalent to IUCN category II) and natural parks (equivalent to IUCN category $\mathrm{V})$ cover more than half of the total protected area surfacenatural parks (37.60\%) and national parks (16.10\%; Law no. 5/2000; H.G. nr. 2151/2004; H.G. nr. 1581/2005, H.G. 1143/2007).

The Romanian national and natural parks are known for the rich diversity of fauna and flora with unique and endangered species, for the various recreation uses (hiking, fishing, camping, climbing, skiing etc.) and for commercial uses as well (ecotourism, hunting tours, camp places, forest fruits etc.). These natural areas have extremely high ecologic, cultural, recreation and tourism values, attracting the necessity of being continuously managed. Efficient management planning should be developed based on the ecological, cultural, social and economic values of protected areas, as it is recommended by IUCN. In this sense, it was published a guide for the managers of protected areas in which it is explained the concept of economic valuation as well as the ways of applying the non-market valuation methods in the case of protected areas (IUCN, 1998). The total economic value of a protected area originates in the utility of goods and services offered, which may represent sources of revenues for the area. Proper management practices may assure a continuous flow of goods and services without diminishing the value of the protected area, with the opportunity of directing revenues towards the conservation of the area (IUCN, 1998). 
The economic values of natural areas represent useful information for decision makers that act in the development of environmental policies, management plans and strategies. For instance, this type of information is useful and important in the decision processes at the level of park administrations, especially when there are more alternative activities that can be offered to tourists (Turner, 2000). Moreover, emphasizing benefits obtained by tourists by performing recreation activities indirectly contributes to the justification of environment conservation (Eagles et al., 2002).

The purpose of this paper is to offer a clear image and as complete as possible on the researches conducted at international level on non-market valuation of national and natural parks with the intention to prove the importance of granting special attention to this subject in Romania also. The rich experience of countries worldwide attests the role and importance of the economic valuation in decision processes. This paper begins with a brief presentation of the most popular methods used in valuing natural areas. It continues with revealing several studies conducted worldwide and an analysis of the case of Romanian national and natural parks. Towards the end, conclusions and potential issues are brought in the attention of the researchers.

\section{Empirical methods for measuring non-market values}

The literature presents many non-market valuation methods developed to value public goods. The stated preferences methods are used when individuals' behavior and/or reaction to the problem is determined based on a hypothetical framework and revealed preference methods when individuals' actual behavior is determined based on a current situation. The methods continue to be improved, adapted and even extended on new fields. In the case of valuing natural areas, researchers focused their work on estimating welfare measures such as Willingness To Pay (WTP) to visit the areas (Contingent Valuation Method) and consumer surplus per visit (Travel Cost Method). Later, the focus was on determining individuals' preferences towards the use of the areas, the presence of several characteristics and even alternative management actions (Choice Experiments Method).

The three non-market valuation methods may be compared by taking the research steps as analysis criteria. The research steps recommended by the literature (Champ et al., 2003) were grouped in five steps, for a logical comparative analysis of the three methods (Tab. 1).

\section{Non-market valuation studies in national and natural parks}

Non-market valuation studies on natural areas became popular worldwide due to their applicability in real world. The estimation of welfare measures, such as willingness to pay and consumer surplus, differentiating user groups, as well as the analysis of several factors that may influence the decision to visit the area, is today in the attention of many researchers.

Shrestha et al. (2002) estimate the economic value associated with recreational fishing in a wetland from Brasil using the travel cost method. Authors report relatively high economic values for recreational fishing compared with other similar researches. Results indicate that the length of the trip, choice of purchasing the travel package, amount of fish caught and other socio-economic factors influences the demand. Results are important for decision processes regarding the support of recreational fishing as main activity in the area and as reference for valuing similar resources in other ecosystems worldwide.

Boxall et al. (2003) analyze the effect of marginal changes in congestion level during wilderness canoe trips

Tab. 1. Comparative analysis of three non-market valuation methods

\begin{tabular}{|c|c|c|c|}
\hline Method /Criteria & Travel Cost Method $^{a}$ & Contingent Valuation Method ${ }^{\mathrm{b}}$ & Choice Experiments Method $^{c}$ \\
\hline $\begin{array}{l}\text { Problem statement; } \\
\text { objectives }\end{array}$ & $\begin{array}{l}\text {-reflects a real situation } \\
\text {-analyzes the actual behavior }\end{array}$ & $\begin{array}{l}\text {-reflects a hypothetical situation } \\
\text {-predicts individuals' behavior }\end{array}$ & $\begin{array}{l}\text {-reflects a hypothetical situation } \\
\text {-predicts individuals' behavior }\end{array}$ \\
\hline Valuation questions design & $\begin{array}{l}\text {-open questions with answers } \\
\text { based on current status } \\
\text {-simple design }\end{array}$ & $\begin{array}{l}\text {-dichotomous choice } \\
\text { valuation questions } \\
\text {-high degree of complexity }\end{array}$ & $\begin{array}{l}\text {-scenarios } \\
\text {-highest degree of complexity }\end{array}$ \\
\hline Questionnaire design & $\begin{array}{l}\text {-questions addressed } \\
\text { at the beginning }\end{array}$ & $\begin{array}{l}\text {-questions addressed after } \\
\text { introductory part }\end{array}$ & $\begin{array}{l}\text {-questions addressed after } \\
\text { introductory part / end part }\end{array}$ \\
\hline $\begin{array}{l}\text { Data collection and } \\
\text { administration }\end{array}$ & $\begin{array}{l}\text {-no additional } \\
\text { explanations required } \\
\text {-quantitative data } \rightarrow \text { variables } \\
\text { constructed directly }\end{array}$ & $\begin{array}{l}\text {-additional explanations required } \\
\text {-quantitative data } \rightarrow \text { variables } \\
\text { constructed directly } \\
\text {-qualitative data } \rightarrow \text { use } \\
\text { dummy variables }\end{array}$ & $\begin{array}{l}\text {-additional explanations always required } \\
\text {-quantitative data } \rightarrow \text { variables } \\
\text { constructed directly } \\
\text {-qualitative data } \rightarrow \text { use effects code }\end{array}$ \\
\hline $\begin{array}{l}\text { Model specification } \\
\text { and determination of } \\
\text { welfare measures }\end{array}$ & $\begin{array}{l}\text {-Travel cost model } \\
\text {-Poisson model } \\
\text {-Consumer surplus }\end{array}$ & $\begin{array}{l}\text {-Random utility model } \\
\text {-Random effects probit -model } \\
\text {-Willingness to pay }\end{array}$ & $\begin{array}{l}\text {-Random utility model } \\
\text {-Multinomial logit model } \\
\text {-Marginal willingness to pay; } \\
\text { consumer preferences }\end{array}$ \\
\hline
\end{tabular}

${ }^{\mathrm{a}}$ Method used by Shrestha el al. (2002); 'Method used by Boxall el al. (2003), Huhtala (2004), Rollins et al. (2008); 'Method used by Hearne and Salinas (2002), Morey et al. (2002), Haider et al. (2004) 
136

in three wilderness parks from Ontario, using the contingent valuation method. They treat for the first time in literature the individuals' preferences as being heterogeneous given that homogeneous preferences may lead to incorrect welfare measures and overestimated congestion costs. The random utility model is used as a panel to value changes in congestion during four different parts of wilderness canoe trips. The results were used by park managers for optimizing the visits by imposing entrance restrictions and reorganizing tourists flow such that congestion is avoided at the main points during the trip. The model proposed by Boxall et al. (2003) was further developed and used to estimate the marginal changes in WTP for changes in congestion levels for recreation trips, for different points within a trip, and for different recreational activities (Rollins et al., 2008). Other analyses referred to the estimation of the WTP for the same trip and for several recreation activities when the vehicle payment was an increase in travel costs. Results served as decision factors for developing management plan for the new designated parks from Ontario and the substitutable areas as well, respectively areas with similar characteristics.

Another interesting subject is the level of the entrance fee for national parks. For instance, there is no park entrance fee in Finland, decision justified by the fact that the entrance fee is covered in one way or another by the general taxes paid by the entire society. Huhtala (2004) analyze tourists' reaction towards introducing an entrance fee in the national parks from Finland as a recreation pass or an increase in the general tax, which includes a quota for recreation. The contingent valuation method was used to estimate WTP values. The increase of the general tax was refused based on the argument that it is already high. The recreation pass was rejected as well, respondents motivating that visiting the areas is not so important. The majority of tourists are satisfied with the current situation that all recreation services are paid by the entire society. They stated that an increase in tax would result in the migration of tourists towards other areas, where there is no entrance fee.

The use of choice experiments method is relatively new for valuing protected areas, its application being popular in marketing. Haider et al. (2004) study the participation of residents to recreation activities in Jasper National Park from Canada and the attitude of tourists towards several management actions. The analysis allowed the recognition of congested situations caused by the presence of several types of users, as well as the reactions to potential use restrictions. Results indicated that residents spend on average 20 days per month performing recreation activities on the trails of the park, the majority being engaged in several activities. More types of users were distinguished (hikers, joggers, mountain bikers, horseback riders) each with different preferences. Authors concluded that potential conflicts among different users may be avoided if they are separated based on the recreation activities.
Hearne and Salinas (2002) analyze national and international tourists' preferences towards the development of a volcanic area situated inside the Braulio Carrillo National Park from Costa Rica. The number of visits has increased significantly after opening a new access way. For that reason, managers recognized the importance to develop a new management plan. The attributes included in the scenarios are infrastructure, type of information offered, availability of aerial trams and observation towers, use restrictions and entrance fee. Tourists' preferences were determined using the choice experiments method. Both tourists' categories prefer an improved infrastructure, presence of aerial trams and observation towers, as well as more information about services offered, and lower entrance fees. The results of this study were used by managers in their decisions taken for the development of the area.

Use conflicts of trails within a park are frequent due to different recreation activities, as it is the case of mountain biking and hiking. At the beginning of ' 80 s, US park administrations noticed that environment degradation is cause by the large number of tourists that are involved in mountain biking. Consequently, park administrations have either forbid mountain biking on some trails or introduced an access fee to collect funds for maintaining the trails. Morey et al. (2002) estimate the impact of introducing an entrance fee for mountain bikers. The choice experiments method is used to estimate the value associated to bikers from the Oregon state (US) for several hypothetical changes of the trails' characteristics. The areas for mountain biking are described using six attributes, among five about the trail and one entrance fee. Results indicate that a significant number of bikers are willing to pay an entrance fee only if the conditions are improved.

Non-market valuation studies on natural areas are not popular in Romania, as it is the case of many East-European countries, where major changes regarding nature protection began only a few years ago. Researches focused mainly on ecological aspects, the economic aspects being neglected or incompletely analyzed. In the developed countries, such studies are periodically conducted to upgrade the economic values. Furthermore, the economic values are used to adapt management plans not only to the needs of potential consumers, but to the requirements imposed by environmental legislation as well, which in Romania is in a continuous process of improvement.

The first non-market valuation study on Romanian national and natural parks was conducted in the period 2005-2008 (Dumitras, 2008). The use of econometric models allowed the estimation of welfare measures that emphasize the amount of money tourists would be willing to pay to take trips in national and natural parks in Romania, and the benefit obtained by performing recreation activities based on the actual costs. Results indicate that tourists gain a benefit after visiting the parks, expressed with the aid of the consumer surplus as welfare measure (Tab. 2). Consumer surplus differs among parks and re- 
Tab. 2. Welfare measures by park $\left(\mathrm{RON}^{\mathrm{c}}\right)$

\begin{tabular}{|c|c|c|c|c|}
\hline Park & Welfare measure (RON) & Distance $\leq 150 \mathrm{~km}$ & Distance $151-300 \mathrm{~km}$ & Distance $>300 \mathrm{~km}$ \\
\hline \multirow{2}{*}{ Bucegi Natural Park } & Median WTPa & 22.18 & 28.02 & 29.22 \\
\hline & Consumer surplus ${ }^{b}$ & 190.08 & 188.76 & 210.53 \\
\hline \multirow{2}{*}{ Cozia National Park } & Median WTPa & 25.25 & 32.51 & 33.77 \\
\hline & Consumer surplus ${ }^{\mathrm{b}}$ & 118.95 & 118.00 & 129.00 \\
\hline \multirow{2}{*}{ Domogled National Park } & Median WTPa & 41.95 & 51.22 & 61.23 \\
\hline & Consumer surplus ${ }^{b}$ & 204.20 & 207.17 & 252.25 \\
\hline \multirow{2}{*}{ Piatra Craiului National Park } & Median WTP ${ }^{a}$ & 63.99 & 73.17 & 75.62 \\
\hline & Consumer surplus ${ }^{\mathrm{b}}$ & 131.11 & 124.33 & 144.86 \\
\hline \multirow{2}{*}{ Porțile de Fier Natural Park } & Median WTPa & 40.45 & 45.82 & NR \\
\hline & Consumer surplus ${ }^{\mathrm{b}}$ & 104.40 & 108.77 & NR \\
\hline
\end{tabular}

${ }^{a}$ estimated using the contingent valuation method; ${ }^{b}$ estimated using the travel cost method; NR = No respondent; The annual average exchange rate for the year 2005 was $1 \mathrm{EURO}=3.6221 \mathrm{RON}$

spondents depending on the traveled distance. These results indicate the actual behavior of visitors. The consumer surplus is greater for tourists who traveled longer distances in all cases, besides those who have traveled 151-300 km to visit Piatra Craiului. Moreover, visitors' behavior was analyzed by building a hypothetical framework, to determine the willingness to pay per trip if the vehicle payment is an increase in travel costs. Special attention was given to the influence of the distance on travel costs. According to the results, tourists who have traveled longer distances are willing to pay, on average more than those who have traveled smaller distances (Tab. 2).

Besides these two measures, the marginal WTP values were estimated for several characteristics of natural public areas, offered in a hypothetical frame using scenarios. Results indicate that tourists have different preferences for trips taken in the natural areas and different expectations for services offered. Unanimous disagreement was stated for the presence of watersides, the areas with karstic relief and steep slopes being preferred. An interesting result is that of studying the list with endangered species. In this sense, tourists from Piatra Craiului and Porțile de Fier showed indifference, even if positive values were obtained, these being very close to zero. A complete disagreement was registered from tourists visiting Bucegi and Cozia, who do not consider it necessary. However, one group of tourists believes it is useful to study the list, tourists who visited Domogled-Valea Cernei.

\section{Conclusions}

All studies analyzed in this paper reveal useful information for park managers, either for establishing an entrance fee, for sustainable planning under increasing demand, or even for ecotourism development. The efficiency of using non-market valuation methods is proved due to the applicability of the results in practice. The choice of the methods depends on the welfare measures needed for decision processes. The results of the research conducted in Romania until nowadays provide merely a first sight of the economic values of the national and natural parks. It is of high interest to investigate further the areas, by identifying the way of using the economic values in the management plans, and by a periodically estimation of such values to validate results and continuously update the database. This information is useful in the decision processes taken at the level of park administrations, through this the recommendations of IUCN being accomplished. Researches on economic valuation constitute significant informative basis for park managers and to policy decision makers as well.

\section{Acknowledgments}

This study has been funded by CNCSIS grant PD $271 / 2010$

\section{References}

Boxall P, Rollins K, Englin J (2003). Heterogeneous preferences for congestion during a wilderness experience. Resource Energy Econ 25(2):177-195.

Champ P, Boyle KJ, Brown TC (2003). A primer on nonmarket valuation. Kluwer Academic Publishers.

Dumitras DE (2008). Estimation of welfare measures in the rural area. University of Agricultural Sciences and Veterinary Medicine Cluj-Napoca, PhD Diss.

Eagles PFJ, McCool SF, Haynes CD (2002). Sustainable tourism in protected areas: guidelines for planning and management. IUCN Gland, Switzerland and Cambridge.

Haider W, Anderson C, Beardmore B, Anderson DA (2004). Recreational trail use of residents in Jasper National Park, Canada. Working Papers of the Finnish Forest Research Institute 2:85-92.

Hearne RR, Salinas ZM (2002). The use of choice experiments in the analysis of tourist preferences for ecotourism development in Costa Rica. J of Env Management 65:153163.

Huhtala A (2004). What price recreation in Finland? -A contingent valuation case study of non-market benefits of public outdoor recreation areas. J Leisure Res 36(1):23-44.

IUCN (1994). Guidelines for protected area management 
138

Categories. IUCN, Gland, Switzerland and Cambridge, UK.

IUCN (1998). Economic values of protected areas: guidelines for protected area managers. IUCN, Gland, Switzerland and Cambridge, UK.

Morey ER, Buchanan T, Waldman DM (2002). Estimating the benefits and costs to mountain bikers of changes in trail characteristics, access fees, and site closures: choice experiments and benefits transfer. J of Env. Management 64:411-422.
Rollins K, Dumitras D, Castledine A (2008). An analysis of congestion effects across and within multiple recreation activities. Can J Agr Econ 56(1):95-116.

Shrestha RK, Seidl AF, Moraes AS (2002). Value of recreational fishing in the Brazilian Pantanal: a travel cost analysis using count data models. Ecolog Econ 42:289-299.

Turner RW (2000). Managing multiple activities in a national park. Land Econ 76(3):474-485. 